\title{
Unngå biologiske legemidler
}

\author{
Legemidler med selektiv effekt på molekylære prosesser ved inflammasjon og kronisk sykdom \\ bør ikke omtales som biologiske legemidler. En slik betegnelse er lite dekkende, sier intet om \\ virkningsmekanismer og tilslører risikoen for bivirkninger.
}

\begin{abstract}
Økt innsikt i molekylære og immunologiske prosesser ved sykdom og moderne bioteknologiske produksjonsmetoder har ført til en lang rekke nye legemidler mot bl.a. autoimmune inflammatoriske sykdommer og kreft. Mest kjent er ulike TNF- $\alpha$-hemmere, bl.a. infliximab og etanercept. Slike midler hemmer selektivt spesifikke reaksjoner i den inflammatoriske prosess ved Crohns sykdom, revmatoid artritt og psoriasis. Nye midler med andre målpunkter i inflammasjonen kommer stadig til, bl.a. ulike anticytokiner. I hovedsak dreier dette seg om monoklonale antistoffer og fusjonsproteiner, produsert ved bruk av komplisert og tidkrevende DNA-rekombinantteknologi.

Disse legemidlene omtales gjerne som «biologiske» legemidler, såkalte biologiske legemidler eller biologiske legemidler.

På engelsk benyttes tilsvarende betegnelser; dessuten er biologics og biologicals mye
\end{abstract}

brukt. Disse betegnelsene brukes i alle ledende medisinskvitenskapelige tidsskrifter, av nasjonale legemiddelmyndigheter og av organene for legemiddelnomenklatur i USA og Verdens helseorganisasjon.

Det foreligger likevel mange definisjoner av begrepet biologics, og søk på Google gir til dels motstridende definisjoner (ramme 1) (1). De fleste inneholder et krav om at midlene er fremstilt fra biologisk materiale i motsetning til syntetisk fremstilte legemidler. Noen har med en presisering om at «biologisk» i denne sammenheng også omfatter moderne bioteknologi, mens andre definisjoner kun omfatter midler produsert ved bioteknologiske metoder. Andre definisjoner legger vekt på midlenes spesifikke biologiske effekt, for eksempel immunmodulering. Definisjonene er altså basert på midlenes opphav, produksjonsmåte og/eller virkningsmekanisme.

\section{Ramme 1}

\section{Utvalgte definisjoner av biologics ved søk på Google (1)}

- Biologics include a wide range of medicinal products such as vaccines, blood and blood components, allergenics, somatic cells, gene therapy, tissues, and recombinant therapeutic proteins created by biological processes (as distinguished from chemistry)

- An extremely complex drug, vaccine or antitoxin that is made from a living organism, or from products of a living organism; of or pertaining to biology; pertaining to a living or a once-living organism

- A classification of products derived from living sources, such as humans, animals, bacteria and viruses. Vaccines, immune globulin, and anti-toxins are biologics.

\section{A biological product used in medicine}

A new class of medications that specifically targets parts of the immune system

A new class of systemic therapies that contain proteins derived from living cells, as opposed to traditional pharmaceutical drugs that are made up of non-living chemicals.

- All viruses, serums, toxins, and analogous products of natural or synthetic origin, such as diagnostics, antitoxins, vaccines, live microorganisms, killed microorganisms, and the antigenic or immunizing components of microorganisms intended for use in the diagnosis, treatment, or prevention of diseases

Protein- or peptide-based therapeutic (e.g. vaccines, monoclonal antibodies)

A drug made from a living organism that is used in the diagnosis or treatment of disease.

A virus, serum, toxin, antitoxin, vaccine, blood, blood component or derivative, allergenic product, or other similar product used to prevent, treat or cure disease or injury

A therapeutic agent derived from living things

Agents of biological origin that are used to diagnose or treat disease

Encompass most drugs whose manufacture involves purification from biological sources such as human or animal tissue or body fluids, or micro-organisms, including those derived using biotechnology

\section{Biologiske produkter}

Juridisk har det lenge vært et skille mellom biologiske produkter og legemidler $(2,3)$. I 1902 vedtok den amerikanske kongressen en lov om biologiske produkter, kjent som Biologics Control Act, som omfattet bl.a. virus, serum, toksiner, antitoksiner, vaksiner, blod, blodkomponenter, allergene produkter og arsenikk brukt i medisinsk sammenheng. Dette er altså den opprinnelige betydningen av ordet biologics. Loven la særlig vekt på produksjonsprosessen. Fire år senere ble en lov om legemidler vedtatt, omtalt som Pure Food and Drug $A c t$, som i større grad var rettet mot produktspesifikasjon, testing og merking.

Dette skillet mellom biologiske produkter og legemidler hadde flere medisinske begrunnelser, bl.a. besto biologiske produkter av store molekyler som var vanskeligere å karakterisere strukturelt, og de kunne lettere overføre smitte og oftere fremkalle anafylaktiske reaksjoner.

Med store vitenskapelige fremskritt etter den annen verdenskrig ble imidlertid skillet mellom biologiske produkter og (syntetiske) legemidler gradvis mer komplisert og uklart (2-4). Ved bruk av moderne bioteknologi ble forskere i stand til å fremstille store molekyler som var identiske eller nær identiske med biologisk forekommende molekyler med spesifikke biologiske virkninger. Nye begreper som biopharmaceuticals og biologic response modifiers oppsto. Da var veien ikke lang til begrepene biological drugs, biologic drugs og biologics som betegnelse for de nye midlene. Betydningen av ordet biologics ble følgelig utvidet og delvis endret. I 1996 ble slike legemidler i USA i praksis likestilt med konvensjonelle legemidler i regulatorisk sammenheng (5).

For legemiddelfirmaene var det klart at slike begreper ville selge bedre enn mer kompliserte og lengre betegnelser. For leger og forskere som vil uttrykke seg kortfattet, både muntlig og skriftlig, var det beleilig å ha en kort betegnelse å ty til. For å understreke betegnelsenes utilstrekkelighet slengte man gjerne på et såkalt eller brukte hermetegn. Etter hvert ble dette sløyfet for å gjøre uttrykket enda enklere.

Med den store oppmerksomheten disse midlene har fått i klinisk medisin er det grunn til å tro at svært mange leger vil oppfatte biologics som en betegnelse på moderne, bioteknologisk fremstilte lege- 


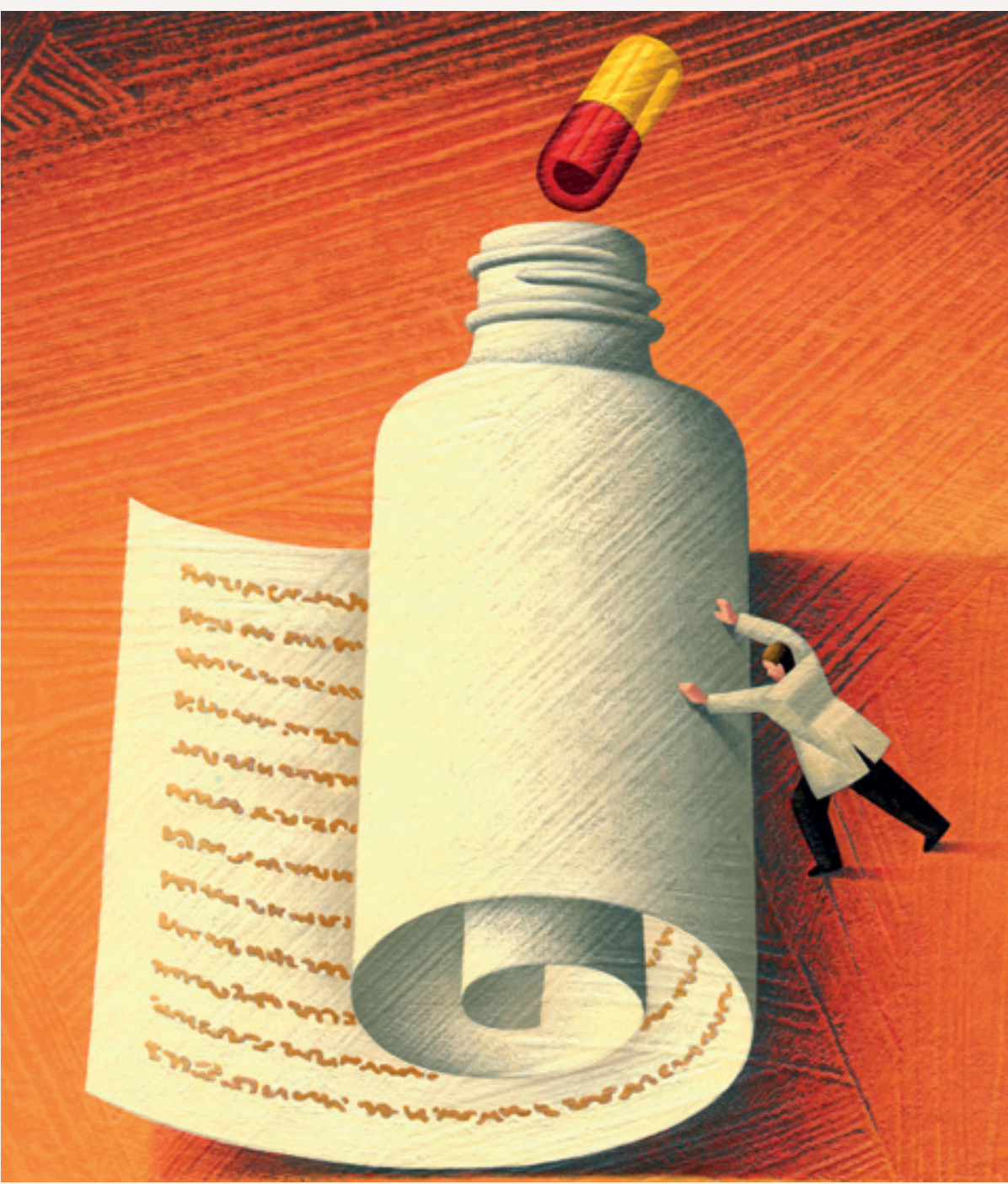

Legemidler fremstilt ved hjelp av moderne bioteknologiske produksjonsmetoder må betegnes på en mest mulig presis og dekkende måte. (c) Adam Niklewicz, Images.com

midler. Noen definisjoner av biologics omfatter kun slike midler (1). Ordet har altså i stor grad fått en annen betydning enn den opprinnelige.

\section{Problematisk}

Vi mener betegnelsen biologiske legemidler (med variasjoner) er problematisk. Den gir inntrykk av at medikamentene er «milde» og «naturlige» og har få bivirkninger. Det motsatte er tilfellet. Legemidler med selektivt immunmodulerende effekt på autoimmune inflammatoriske sykdommer bør etter vår oppfatning heller betegnes som selektivt immunmodulerende legemidler - det er mer dekkende, mer presist og mer forståelig, $\mathrm{i}$ hvert fall for leger. Tilsvarende uttrykk er brukt i mange vitenskapelige publikasjoner på engelsk (selective immunomodulating drugs eller agents). Pasienter og pårørende må uansett gis informasjon på en forståelig, dekkende og nøktern måte og ikke gis et feilaktig inntrykk av legemidlenes opphav, karakter eller bivirkningsrisiko.

Eli Nordal foreslo i Tidsskriftet for en tid tilbake å benytte uttrykket biologika (i entall biologikum) (6). Språklig sett er dette i form og innhold en direkte oversettelse av biologics og en parallell til antibiotika (på engelsk: antibiotics) og andre typer farmaka. Men skal man legge vekt på midlenes overordnede virkning, slik som ved antibiotika, antimykotika og cytostatika, burde betegnelsen heller bli antibiologika (på engelsk: antibiologics), for dette er legemidler som motvirker - ikke fremmer - biologiske prosesser.

Vi er ikke de eneste som tar opp det problematiske ved nomenklaturen innen dette feltet. Kenneth Katz, en amerikansk dermatolog, skrev i 2006 en kritisk lederartikkel i British Journal of Dermatology (2), og advokaten Edward Korwek publiserte i 2007 en omfattende analyse av begrepet biologics i et juridisk tidsskrift (3). I en lang kommentarartikkel i Nature Biotechnology i 2008 påpekte Ronald Rader at begrepsforvirringen omkring biopharmaceuticals (og liknende uttrykk) er langt mer enn bare semantikk (4). Men disse artiklene er lite sitert i vitenskapelig artikler, ifølge våre søk henholdsvis bare seks, fem og tre ganger per dags dato (21.7. 2010).

Årsakene til denne manglende interessen kan være mange. De fleste leger er mer opptatt av midlenes kliniske effekter enn av det mange vil oppfatte som språklige detaljer og petitesser. Leger kan være tilbakeholdne med å kritisere produsenter av legemidler de selv forskriver til sine alvorlige syke pasienter. Mange er involvert i utprøvning og markedsføring av legemidlene og mottar støtte til kongressreiser og forskningsprosjekter. Men det kan også skyldes at de er uenig i eller stiller seg likegyldig eller avvisende til kritikken.

\section{Konklusjon}

Betegnelsene «biologiske» legemidler, såkalte biologiske legemidler, biologiske legemidler og biologika bør i størst mulig grad unngås. Istedenfor bør forfattere og leger heller skrive og si mer eksplisitt hvilket legemiddel eller type legemiddel man omtaler, for eksempel infliximab, etanercept, TNF- $\alpha$-hemmere, monoklonale antistoffer og liknende, eventuelt med en kort angivelse av virkningsmekanisme. Ved behov for et mer omfattende samlebegrep for midler mot inflammatorisk sykdom foreslår vi uttrykket selektivt immunmodulerende legemidler, gjerne med en kort forklaring og omtale av begrepsbruken.

\section{Petter Gjersvik}

petter.gjersvik@medisin.uio.no Institutt for klinisk medisin

\section{Michael Bretthauer}

Enhet for kolorektal screening Kreftregisteret

Oslo universitetssykehus, Rikshospitalet 0027 Oslo

\section{Vi takker Erlend Hem for nyttige kommentarer.}

Oppgitte interessekonflikter: Petter Gjersvik har fått dekket utgifter ved kongressdeltakelse og mottatt foredragshonorar av firmaer som produserer og markedsfører selektivt immunmodulerende legemidler. Begge forfattere har bistilling som medisinsk redaktør i Tidsskriftet.

\section{Litteratur}

1. Søk: «define: Biologics». www.google.com (21.7.2010)

2. Katz KA. «Biologics»: a clinically meaningless term. Br J Dermatol 2006; 154: 809-12.

3. Korwek EL. What are biologics? A comparative legislative, regulatory and scientific analysis. Food Drug Law J 2007; 62: 257-304.

4. Rader RA. (Re)defining biopharmaceutical. Nat Biotechnology 2008; 26: 743-51.

5. Gamerman GE, Mackler BF, Landa MM. «1996» starting the modern era of biologics regulation: FDA's elimination of established licensure and other changes. Biotechnol Appl Biochem 1997; 25 189-95.

6. Nordal EJ. Hvorfor ikke «biologika»? Tidsskr Nor Legeforen 2008; 128: 2356. 